\title{
Due Process Hearing Officers: Characteristics, Needs, and Appointment Criteria
}

\author{
ANN P. TURNBULL \\ BONNIE STRICKLAND \\ H. RUTHERFORD TURNBULL
}

\begin{abstract}
Characteristics and training needs of due process hearing officers in North Carolina were surveyed. It was found that current regulations governing appointments of hearing officers are insufficient to ensure appointment of qualified and impartial persons. Criteria were analyzed and suggestions for training and appointments are made.
\end{abstract}

ANN P. TURNBULL is Research Associate, Bureau of Child Research, University of Kansas, Lawrence; BONNIE STRICKLAND is Administrative Assistant, Division for Special Education, University of North Carolina at Chapel Hill, and a due process hearing officer; and $\mathrm{H}$. RUTHERFORD TURNBULL is Chairman, Department of Special Education, University of Kansas, Lawrence.
Due process assures fairness in the identification, evaluation, and placement of handicapped students in special education and related services. To ensure due process, handicapped students and their representatives and/or the local educational agency may request a hearing to protest each other's decisions. The local education agency or state education agency is required to appoint an impartial hearing officer. Some hearing officers are appointed by the state education agency (e.g., in Illinois), while others are appointed by local education agencies (e.g., in North Carolina, where they are appointed by local education agency superintendents).

A hearing may not be conducted by an employee of a public agency involved in the education or care of the child, or by any person with a personal or professional interest which conflicts with objectivity in the hearing. A person who otherwise qualifies to conduct a hearing is not an employee of the agency solely because he or she is paid by the agency to serve as a hearing officer. Each public agency must keep a list of hearing officers, including a statement of the qualifications of each (Federal Register, Sec. 121a.507, p. 42495).

It is unclear whether or not hearing officers are "qualified" by their impartiality alone' or if they must also be professionally qualified (Turnbull, Turnbull, \& Strickland, 1979). The

Exceptional Children, Volume 48, Number 1. Copyright ${ }^{\circ} 1981$ The Council for Exceptional Children. 
regulations are deficient in not specifying the criteria for determining both impartiality and other qualifications. Thus, state education agencies and local education agencies have substantial latitude in the appointment of officers.

An important issue in the effective implementation of due process safeguards, not yet addressed in the literature, focuses on hearing officers' attributes. Who are they? What is their professional background? What criteria are used in appointing them? What are the conditions of their appointment?

These and other questions formed the basis of a survey that provides a profile of the characteristics of hearing officers in North Carolina, their perceived needs in terms of executing their responsibilities, and the selection criteria used by local education agencies in appointing them. The survey findings have implications for local policy and research.

\section{METHOD}

\section{Respondents}

The respondents to the survey were 44 hearing officers and 79 local education agency superintendents in North Carolina. The hearing officers represented approximately $80 \%$ of the officers who had been appointed by the beginning of the 1978-79 school year. The survey was completed by the officers at the initial session of a 2 day training conference sponsored by the Institute of Government at The University of North Carolina at Chapel Hill in August 1978. (Hearing officers who did not attend the conference were not included in the survey.) At that time, none of the respondents had prior experience as hearing officers in matters pertaining to a free appropriate public education of handicapped students.

Superintendents were chosen as respondents to represent the interests of the local education agency in the appointment process, since they serve as chief executive officers of the local education agencies and are required by North Carolina legislation to appoint the hearing officers. The survey was mailed during the fall of 1978 to all superintendents in North Carolina.

The survey was completed by 79 superintendents (a $54 \%$ return rate). A substantial number of the superintendents not responding to the survey were in local education agencies that either had not appointed a hearing officer or had arranged to use the services of an officer previously appointed by a nearby local education agency. The authors were unable to determine how many responding superintendents had appointed a hearing officer.

Different questionnaires were developed for hearing officers and for superintendents. The hearing officers' questionnaire, with 17 items, was divided into four parts: personal characteristics; community and school involvement; reasons for serving as a hearing officer; and execution of responsibilities.

The superintendents' questionnaire included 12 items covering the following three topics: selection process; execution of responsibilities; and compensation and service commitment.

For most questionnaire items respondents either checked the one answer which applied (e.g., income range; number of hearing officers retained by the local education agency) or rank ordered responses in terms of first, second, and third priorities (e.g., most significant personal obstacles in executing responsibilities; greatest obstacles in the selection of hearing officers).

The percentage of respondents checking each item was computed for the questions requiring a single response. For questions that required a ranking response, the percentage of persons choosing each item as first choice and the priority for each item were computed. Item priority was calculated by converting the rankings to points through a modified nominal group procedure as described by Davis and Humberger (1977). A mean priority ranking of each problem area or issue was provided.

\section{RESULTS}

\section{Hearing Officer Survey}

Personal characteristics. The majority of due process hearing officers were White $(86 \%)$ and male $(80 \%)$. Their ages ranged from 25 to over 65 , with majority clusterings between the ages of $25-35(36 \%)$ and $60-65(25 \%)$. All hearing officers had completed high school; $87 \%$ had completed undergraduate degrees; and $68 \%$ had 1 to 3 years of graduate training. Their academic majors were reported primarily as education $(23 \%)$, history (18\%), and political science $(16 \%)$ at the undergraduate level; and law $(32 \%)$, administration $(20 \%)$, and education $(11 \%)$ at the graduate level. 
In terms of occupation, approximately one third were practicing attorneys and another one third were retired. Almost all retired officers had previously been employed as administrators or teachers in the public schools. Many were serving as officers in the local education agencies for which they had worked for many years. Approximately one quarter (21\%) were professionals currently employed in education in such positions as school superintendents, directors of specialized programs, or college professors. Diversified professions and backgrounds, including a homemaker, postmaster, and research biologist, were represented by $14 \%$ of the hearing officers. The officers' income levels ranged from between $\$ 5,000$ and $\$ 10,000(9 \%)$ to over $\$ 30,000$ (11\%) annually, with $45 \%$ of the officers having annual incomes of between $\$ 15,000$ and $\$ 25,000$.

School involvement. Involvement in school affairs during the past 3 years was indicated by $69 \%$ of the hearing officers. The most often noted involvement was voluntary or elected participation on committees or advisory groups appointed by school boards (25\%). Other noteworthy findings were that $9 \%$ indicated involvement with programs for handicapped students and $16 \%$ indicated no school involvement during the past 3 years.

Three fourths indicated that they had no children currently enrolled in the public schools. Four hearing officers $(9 \%)$ had a handicapped child; in addition, $30 \%$ had other family members who were handicapped.

Reasons for serving as a hearing officer. Table 1 includes a list of the most important reasons identified by the hearing officers for their interest in serving in this capacity.

Execution of responsibilities. The topics rated by hearing officers as areas of greatest need in terms of preparation for their responsibilities are reported in Table 2.

\section{Superintendent Survey}

Selection process. Public Law 94-142 (the Education for All Handicapped Children Act of 1975) Rules and Regulations require the appointment of an impartial hearing officer. Superintendents were requested to indicate the criteria they considered most important in determining impartiality. These criteria are reported in Table 3.
TABLE 1

Most Important Reasons for Interest in Serving as a Due Process Hearing Officer

\begin{tabular}{ccc}
\hline \hline & $\begin{array}{c}\text { Percent of } \\
\text { hearing } \\
\text { officers } \\
\text { choosing } \\
\text { item as first } \\
\text { priority }\end{array}$ & $\begin{array}{c}\text { Weighted } \\
\text { priority } \\
\text { for top 3 } \\
\text { choices }\end{array}$ \\
\hline Reason for interest & & \\
\hline $\begin{array}{c}\text { To contribute to the } \\
\text { solution of } \\
\text { educational } \\
\text { problems }\end{array}$ & 20.6 & 1 \\
$\begin{array}{c}\text { Prior interest in } \\
\text { handicapped } \\
\text { children }\end{array}$ & 41.2 & 2 \\
$\begin{array}{c}\text { Form of civic } \\
\text { responsibility } \\
\text { Opportunity for } \\
\text { professional } \\
\text { development }\end{array}$ & 17.6 & 3 \\
$\begin{array}{c}\text { Financial } \\
\text { reimbursement } \\
\text { Other (e.g., legally } \\
\text { interesting) }\end{array}$ & 20.6 & 4 \\
\hline
\end{tabular}

The qualifications considered by the superintendents in making an officer selection are shown in Table 4.

The greatest obstacles encountered by the superintendents in the selection of hearing officers are reported in Table 5.

In $87 \%$ of the local education agencies, the hearing officer was appointed or requested to serve by the local education agency. In the remaining cases, officers volunteered for service. The number of officers retained by local education agencies ranged from one ( $91 \%$ of the cases) to over five ( $1 \%$ of the cases).

\section{DISCUSSION}

The low incidence of non-White hearing officers was surprising in view of the sensitivity to racial composition shown by North Carolina state rules and regulations, which require that one person on the placement team be of the same race as the child being considered for special education placement (Division for Exceptional Children, 1978). Although neither 
TABLE 2

Areas of Greatest Need in Terms of Preparation for Executing Responsibilities as a Hearing Officer

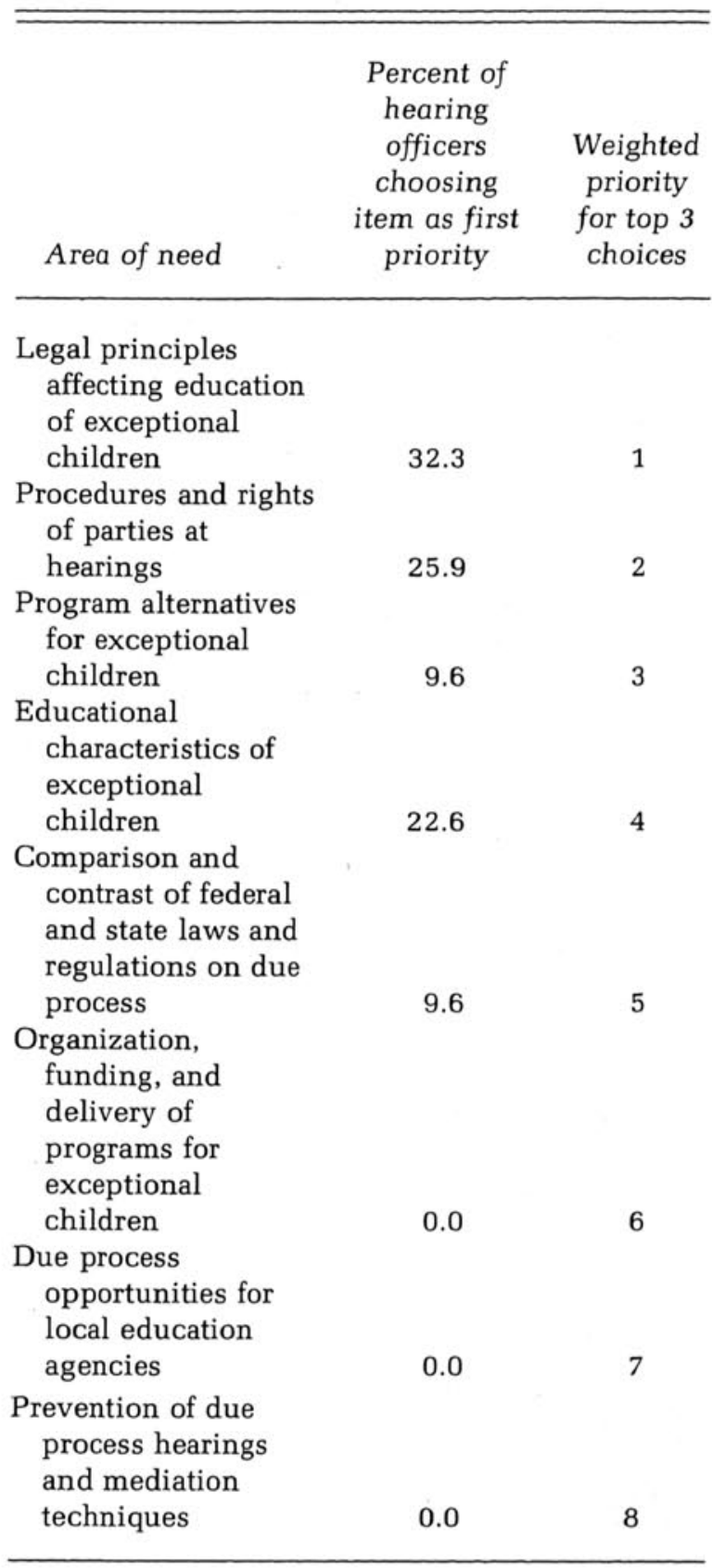

federal nor North Carolina rules require it, local education agencies might be well advised to include hearing officers representative of different racial groups within the community. As noted in the results of this study, $91 \%$ of the local education agencies reported had selected only one hearing officer and $80 \%$ of all hearing officers were White males.
The finding that most (87\%) hearing officers had legal or educational professional backgrounds was not surprising in light of the nature of their responsibilities and the indication by school superintendents that hearing officers' most important qualification is related to legal and educational principles.

Although this study does not specifically address the hearing officers' impartiality, the fact that $48 \%$ were either retired from or currently employed in local education agencies may cause some concern. This is especially

TABLE 3

Criteria for Determining Impartiality

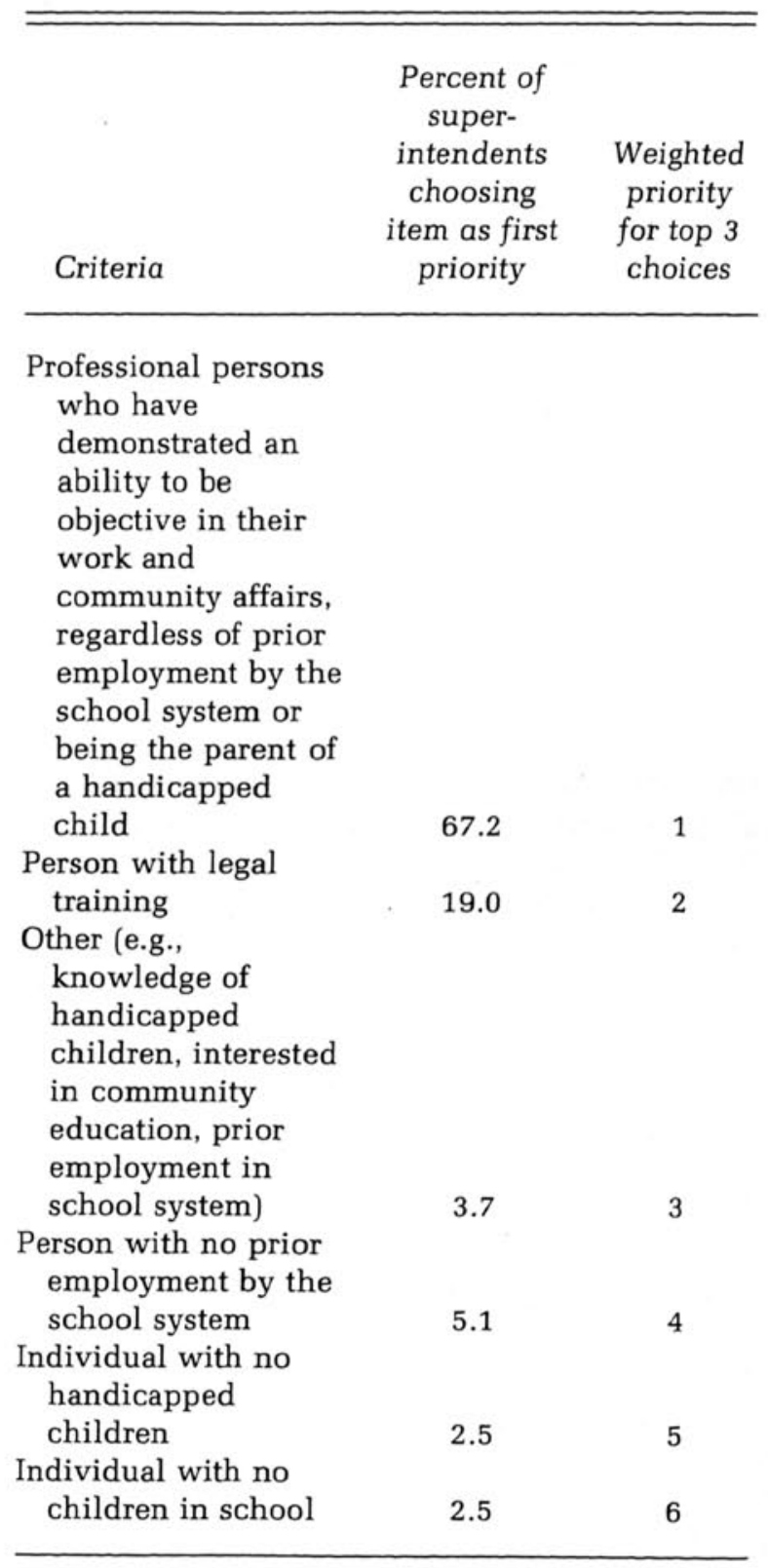


TABLE 4

Qualifications Considered in Selection of Impartial Hearing Officers

\begin{tabular}{lcc}
\hline & $\begin{array}{c}\text { Percent of } \\
\text { super- } \\
\text { intendents } \\
\text { choosing } \\
\text { item as first } \\
\text { priority }\end{array}$ & $\begin{array}{c}\text { Weighted } \\
\text { priority } \\
\text { for top 3 } \\
\text { choices }\end{array}$ \\
\hline Qualifications & 31.6 & 1 \\
\hline $\begin{array}{l}\text { Expertise related to } \\
\text { education in } \\
\text { general }\end{array}$ & 31.6 & 2 \\
$\begin{array}{l}\text { Knowledge of general } \\
\text { legislation }\end{array}$ & & \\
$\begin{array}{l}\text { Expertise in educating } \\
\text { handicapped } \\
\text { students }\end{array}$ & 10.1 & 3 \\
$\begin{array}{l}\text { Expertise in the area } \\
\text { of law as it pertains } \\
\text { to the handicapped }\end{array}$ & 12.6 & 4 \\
$\begin{array}{l}\text { Community member } \\
\text { not professionally } \\
\text { involved in school } \\
\text { but interested in } \\
\text { school affairs }\end{array}$ & 10.1 & \\
$\begin{array}{l}\text { Other (e.g., retired } \\
\text { educators, officer } \\
\text { chosen by another } \\
\text { LEA) }\end{array}$ & & \\
\hline
\end{tabular}

true if the hearing officer has retired from the local education agency in which the hearing occurs or is currently employed by another local education agency that may be indirectly affected by the results of the hearing. P.L. 94142 provides that a hearing officer may not have a personal or professional interest that conflicts with his or her objectivity in the hearing (Federal Register, 1977).

The impartiality of parents of handicapped children as hearing officers (9\%) might also be questioned. It is clearly possible that such officers' handicapped children may be either directly or indirectly affected by their decisions.

The superintendents indicated overwhelmingly that local education agencies' main criterion for determining an officer's impartiality was that the person be a professional who has demonstrated an ability to be objective in work and community affairs, regardless of prior employment by the school system or of being the parent of a handicapped child. Questions about the criteria used to determine a potential hearing officer's objectivity on the basis of race or as a function of prior professional or personal experience were not included in this survey. If such criteria are not clearly defined by superintendents, as may be the case, challenges to officers' impartiality can be anticipated.

TABLE 5

Obstacles to the Appointment of Hearing Officers

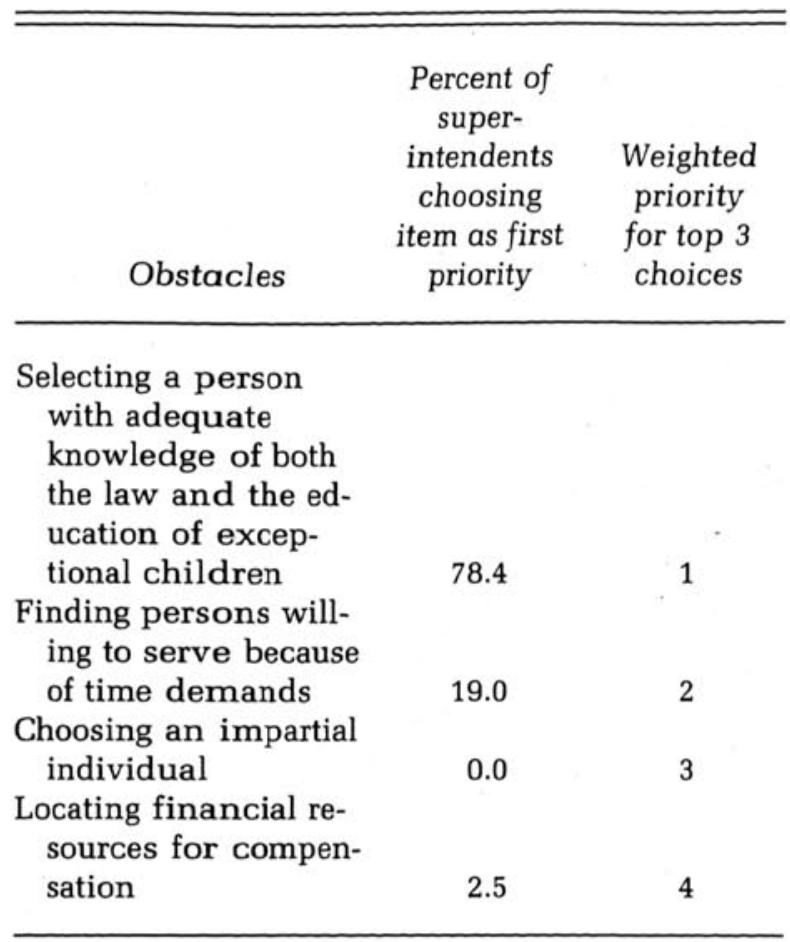

It is interesting to note that $13.6 \%$ of the hearing officers were from backgrounds unrelated to either law or education. Professional bias appears to be eliminated in these selections, but it may be difficult for these officers to render an informed decision, as an inordinate amount of time and local education agency compensation may be necessary for them to acquire information concerning P.L. 94-142 and educational programs. The effectiveness of officers from various professional backgrounds has not been documented to date.

Superintendents indicated that the two qualifications considered most important by local education agencies related to general aspects of law and education, with specific ap- 
plication of these areas to handicapped individuals rated third and fourth. These results were not anticipated, considering that hearing officers with a general knowledge of law and education undoubtedly require time to familiarize themselves with the more specific aspects of law and education for the handicapped, thus increasing compensation for time spent in preparation for hearings and in making decisions related to education for handicapped students.

School superintendents indicated that the greatest obstacles in the appointment of hearing officers were related to finding a person knowledgeable about both law and eduation of handicapped students; however, Table 4 shows that the most important qualification for hearing officers was expertise in the general aspects of both law and education. An individual's impartiality was not chosen as a first priority problem by any superintendent even though the criterion of impartiality is the only requirement addressed by P.L. 94-142 for such selection. In addition, though superintendents seem to recognize that time demands on the hearing officer present a problem (second priority), there is little concern regarding financial resources (fourth priority) to compensate those officers. Perhaps the relatively infrequent hearings occurring when the superintendents completed the questionnaire accounts for their apparent lack of concern regarding financial resources. It is predicted that the required level of compensation might be greater than anticipated by superintendents in the earlier stages of the implementation of the due process requirement of P.L. 94-142, particularly since hearing officers negotiate their compensation with local education agencies.

\section{IMPLICATIONS}

Although the data do not explicitly support each of the following implications, some are fair inferences and others are the authors' opinions, formed as a result of extensive and varied contacts with North Carolina local education agencies, parents of handicapped children, and hearing officers.

\section{Local Education Policy}

Implications for local education agency policy, which should be validated by further research, include:
1. Local education agencies should consider appointing more than one hearing officer to reduce the potential for scheduling conflicts and competing time demands.

2. Local education agencies should develop a more balanced pool of officers (by race and sex) to avoid the appearance of partiality.

3 . For the sake of impartiality, hearing officers should have no previous employment record with the local education agency for which they serve as an officer. Currently employed personnel in one local education agency should not serve as hearing officers in other local education agencies. Parents of handicapped children should not serve as hearing officers.

4. The local education agency should develop and make public the criteria used for determining a prospective officer's impartiality.

5. The local education agency should ensure that, in addition to being impartial, hearing officers are qualified by background and knowledge. If the officer appointed by the superintendent is not qualified, the local education agency should provide training. An assessment of the needs of officers to be trained could provide the basis for planning the training sessions.

\section{Research and Evaluation}

Areas for future research based on the survey's findings might include:

1. Documentation of differences between hearing officers from legal, educational, and other backgrounds to determine the differences in their procedures for reaching decisions and in the types of evidence and testimony they use to support decisions.

2. Comparison of acceptable criteria for determining officers' impartiality as viewed by parents and school personnel involved in due process hearings.

3. Comparison of hearing officers' priority needs before and after involvement in due process hearings.

4. Documentation of average length of service by hearing officers in terms of how many hearing officers complete a specified service period and how many do not, as well as how many serve additional terms beyond the initial service period.

5. Documentation of hearing officers' opinions regarding fair rates of compensation. 
6. Documentation of the average length of due process hearings as well as time spent in preparation and decision making.

7. Evaluation of training programs designed to provide necessary information to hearing officers from varying backgrounds.

8. Comparison of needs assessment information from officers to determine differences in perceived needs according to professional backgrounds, for training purposes.

\section{SUMMARY}

The role of the due process hearing officer is of critical importance in ensuring the impartial resolution of disputes between parents and educators. The regulations governing appointment of hearing officers are insufficient to ensure that impartial and qualified persons are appointed. Systematic investigation and monitoring of credentials of hearing officers and procedures used to appoint them is necessary to refine policy guidelines and to increase the likelihood that handicapped students are provided with an appropriate education.

\section{REFERENCES}

Davis, D. W., \& Humberger, E. Regional human services: Citizen participation. In J. L. Paul, D. J. Stedman, \& G. R. Newseld (Eds.), Deinstitutionalization: Program and policy development. New York: Syracuse University Press, 1977.

Division for Exceptional Children. Rules governing programs and services for children with special needs. Raleigh, NC: State Department of Public Instruction, 1978.

Federal Register. Washington, DC: U.S. Government Printing Office, 1977.

Turnbull, H. R., Turnbull, A. P., \& Strickland, B. Procedural due process: A two-edged sword that the untrained should not unsheath. Journal of Education, 1979, 161, 40-59.

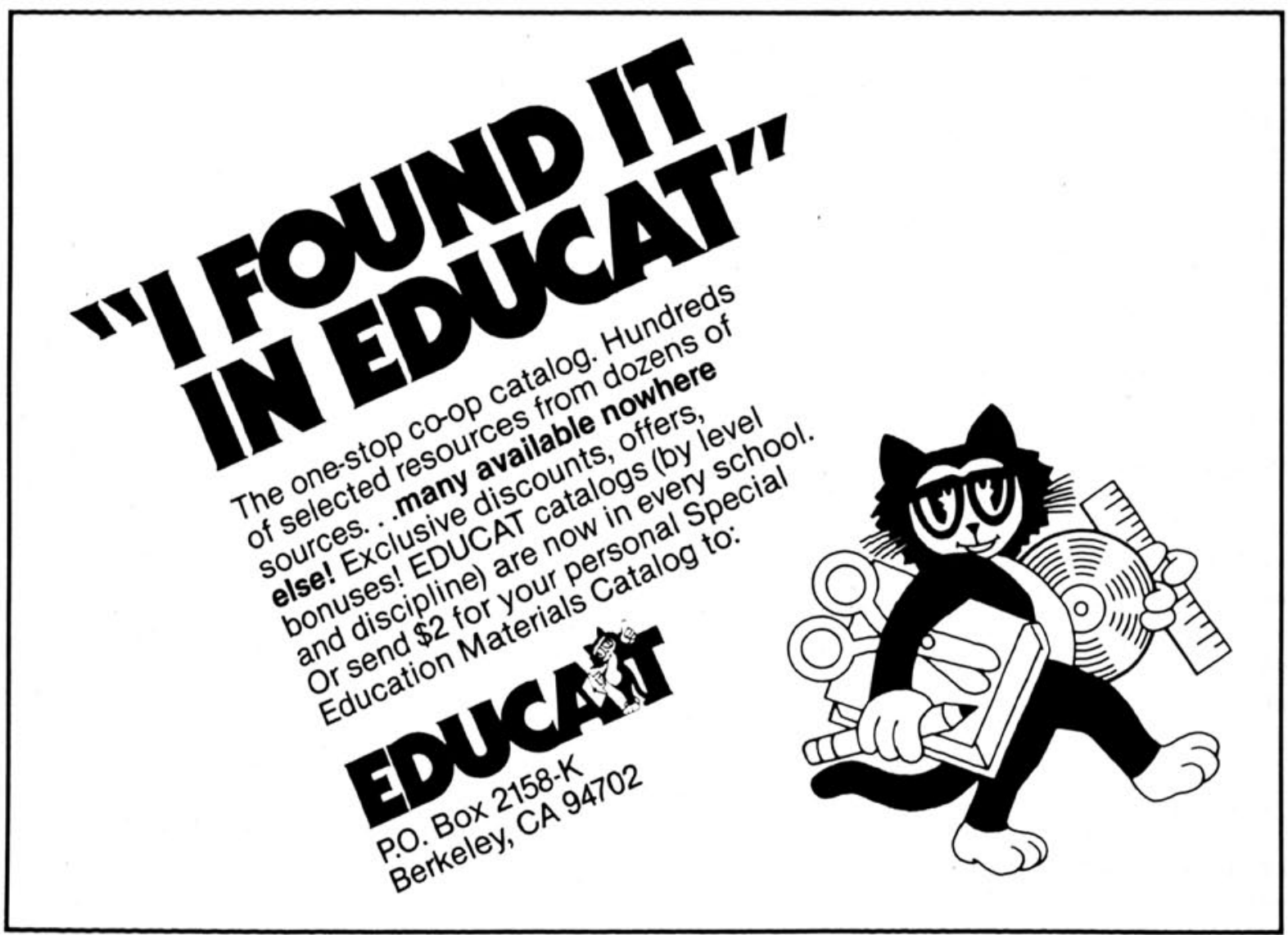

